\title{
Characterological and Psychological Peculiarities of women with eating behavior disorders
}

\author{
Nataliya Lisova \\ IAPM, Kiev, Ukraine
}

Introduction. Concerns about overweight are especially prevalent among women, which is largely aided by media that promote certain standards of feminine beauty and promote various ways to lose weight. Public stereotypes consider the perfect slim woman with a figure inaccessible to the vast majority, causes a sense of inadequacy in women, more or less inclined to fullness.

Purpose of the paper is to highlight current researches on eating behavior disorders among women, and to define characterological peculiarities related to the disorders of eating behavior of women.

Results. The characteristic features of overweight women are frequent depression; addictive behavior, general impulsivity and destructive-compulsive behavior; verbal aggression, violent outbursts; tendency to use the symptoms of their somatic diseases as a means of avoiding responsibility; the desire to attract attention, demonstrative, superficial feelings and interests

Conclusions. Early signs of impaired eating behavior are changes in psychological status, characterized by the appearance of adverse mental reactions: anxiety, frustration, rigidity, irritability and aggressiveness

Keywords: women, eating behavior, psychological qualities 


\section{Характерологічні та психологічні особливості жінок з надмірною масою тіла}

Наталія Лісова, МАУП, Київ, Україна

Актуальність. Стурбованість з приводу надмірної маси особливо поширена серед жінок, чому в великій мірі сприяють засоби масової інформації, що пропагують певні стандарти жіночої краси і рекламують різні способи схуднення. Суспільні стереотипи вважають ідеальною струнку жінку з фігурою, недосяжною для переважної більшості, викликає відчуття неадекватності у жінок, більш-менш схильних до повноти.

Мета статті полягає у огляді сучасних досліджень з проблеми розладів харчової поведінки у жінок та визначенні характерологічних особливостей, взаємопов'язаних 3 порушеннями харчової поведінки у жінок

Результати. Характерологічними особливостями жінок з надмірною вагою вважаються часта депресія; залежність, загальна імпульсивність і деструктивнокомпульсивна поведінка; словесна агресія, вибухи люті; схильність використовувати симптоми своїх соматичних захворювань, як засіб уникнення відповідальності; прагнення звернути на себе увагу, демонстративність, поверховість почуттів і інтересів

Висновки. Ранніми ознаками порушеної харчової поведінки $\epsilon$ зміни у психологічному статусі, які характеризуються появою несприятливих психічних реакцій: тривожності, фрустрації, ригідності, дратівливості та агресивності

Ключові слова: жінки, харчова поведінка, психологічні якості

Актуальність. Останнім часом зростає інтерес дослідників до психологічних аспектів ожиріння, поширеність якого в економічно розвинених країнах, за статистикою BOO3, досягає 30\%, та є фактором ризику не тільки для виникнення проблем зі здоров'ям, але i, порушує соціальну адаптацію та сприяє розвитку дисфункції психіки.

Будучи проблемою, яку важко приховати від оточуючих, надлишкова маса призводить до значного психологічного ризику, зумовленого існуючими в суспільстві негативними установками по відношенню до повних людей. Стурбованість з приводу надмірної маси особливо поширена серед жінок, чому в великій мірі сприяють засоби 
масової інформації, що пропагують певні стандарти жіночої краси і рекламують різні способи схуднення. Сучасне суспільство, вважаючи ідеальною струнку жінку 3 фігурою, недосяжною для переважної більшості, викликає відчуття неадекватності у жінок, більш-менш схильних до повноти. Тому вивчення психологічних особливостей таких жінок є досить актуальним.

Мета статті полягає у огляді сучасних досліджень 3 проблеми розладів харчової поведінки у жінок та визначенні характерологічних особливостей, взаємопов'язаних 3 порушеннями харчової поведінки у жінок.

Результати. Ожиріння лише в 5\% випадків є симптом якогось органічного захворювання. У $95 \%$ випадків в його основі лежить нейрохімічний дефект церебральних систем, які регулюють харчову поведінку і гормональний статус (Greeno, Wing, 1994). При цьому у 60\% хворих на ожиріння має місце патологія харчової поведінки, і їм досить власної сили волі і самоконтролю для успішної боротьби із зайвою масою.

Харчова поведінка - сукупність звичок, пов'язаних 3 прийомом їжі - наші смакові переваги, режим прийому їжі, дієта. Харчова поведінка залежить від багатьох факторів - особливостей культури, виховання, матеріальних можливостей, біологічних особливостей.

Ожиріння - хронічне мультифакторне гетерогенне захворювання, що виявляється надлишковим утворенням жирової тканини, прогресуюче при природному протіканні. Як правило, його супроводжують високий кардіометаболічний ризик, специфічні ускладнення, з ним асоціюються різні захворювання.

Традиційно дослідження ожиріння і харчової поведінки не були зв'язані один 3 одним і проводилися в рамках різних підходів. Ожиріння розглядалося як медичне захворювання, що має генетичну і метаболічну природу, найбільш ефективними способами лікування якого вважалися дієта, лікарські засоби або хірургічне втручання (Бессесен, Кушнер, 2006). На противагу цьому в психіатрії та психотерапії порушення харчової поведінки (нервова анорексія і булімія) розглядалися як синдроми, існуючі переважно в західній культурі, що виникають в суспільствах з надмірним акцентом на проблемах ваги, форми і зовнішнього вигляду, ефективно виліковувати за допомогою когнітивно-поведінкової та сімейної психотерапії (Малкіна-Пих, 2005). 
В даний час в медичній психології існує явний дефіцит досліджень ролі особистості в формуванні харчової поведінки клієнтів з ожирінням, у яких немає вираженої психопатології і які становлять більшість популяції людей 3 ожирінням. Звідси випливає, що в більшості випадків психотерапія може бути єдиним або основним методом в програмі схуднення.

Харчова поведінка людини оцінюється як гармонійна (адекватна) або девіантна залежно від багатьох параметрів, зокрема, від місця, яке займає прийом їжі в ієрархії цінностей індивіда, від якісних і кількісних показників харчування, від естетики. Важливими є фактори вироблення стереотипів харчової поведінки, особливо в період стресу. Одвічним питанням щодо цінності харчування $є$ його зв'язок з життєвими цілями («їсти, щоб жити чи жити, щоб їсти»), врахування ролі харчової поведінки для становлення деяких особистісних характеристик (наприклад, гостинність) (Данильченко, 2004).

Серед порушень харчової поведінки виділяють обмежувальну, екстернальну і емоціогенну харчову поведінку. Обмежувальна харчова поведінка характеризується навмисними зусиллями, спрямованими на досягнення або підтримання бажаної маси за допомогою скорочення споживання калорій. Результати багатьох досліджень показали, що при дистрессі кількість їжі, що з'їдається збільшується у тих, хто дотримується дієти, і зменшується у тих, хто дієту не дотримується (Малкіна-Пих, 2005). Екстернальна харчова поведінка пов'язана 3 підвищеною чутливістю до зовнішніх стимулів до прийому їжі: запаху їжі, іiі зовнішньої привабливості, доступності харчових продуктів. При цьому люди їдять незалежно від того, голодні вони чи ні. При емоціогенній харчовій поведінці бажання поїсти виникає у відповідь на негативні емоційні стани, такі як тривога, страх, гнів, розчарування, пригніченість, нудьга і ін. Відповідно до психосоматичної гіпотези (Kaplan, Kaplan, 1957) ожиріння є наслідком нездатності до розрізнення почуття голоду і стану тривоги, в результаті чого індивід реагує на стрес, як на голод, збільшуючи споживання їжі.

Ранніми ознаками порушеної харчової поведінки є зміни у психологічному статусі, які характеризуються появою несприятливих психічних реакцій: тривожності, фрустрації, ригідності, дратівливості та агресивності. Такі реакції виступають в якості ранніх психологічних критеріїв неврогенних розладів харчування (Менделевич, 2005).

Останнім часом фокус досліджень перемістився з питання про те, чи пов'язано ожиріння з психологічним дистрессом, на питання, які люди 3 ожирінням мають 
підвищений ризик психопатології. В рамках цього підходу J.Istvan з співробітниками (Istvan, Zavel, Weidner, 1992) розглянули взаємозв'язок між індексом маси тіла і депресією на репрезентативній сукупності у дорослих 25-74 років. Вони не виявили взаємозв'язку між індексом маси тіла і депресією серед чоловіків, але виявили, що жінки з індексом маси тіла більше 28,96 кг / м² в 38\% випадків мали клінічно значущі депресивні симптоми в порівнянні з жінками з меншим індексом маси тіла. Результати лонгитюдних досліджень показали, що депресія передує ожирінню у дівчаток-підлітків, але не у хлопчиків, і що ожиріння передує депресії у дорослих (Istvan, Zavel, Weidner, 1992). У свою чергу, такі фізіологічні прояви, як розлади апетиту, значні зміни маси тіла, а також такі поведінкові прояви, як залежність, загальна імпульсивність і деструктивно-компульсивна поведінка, є симптомами депресії (Пезешкіан, 1996).

При порушеннях харчової поведінки досить часто спостерігається депресія. Проте поки не існує наукових даних, що дозволяють 3 усією визначеністю стверджувати, яке 3 цих порушень виникає першим і чи існує між ними причиннонаслідковий зв'язок.

Питання про взаємовідносини надлишкової маси, переїдання i агресії представляє особливий інтерес. Доведено, що емоціями, з якими найбільш пов'язано булімічну поведінку, є тривога, депресія і гнів (Kaplan, Kaplan, 1957). К. Ізард (Musante, Costanzo, Friedman, 1998) зазначав, що, коли людина засмучується з приводу своєї надлишкової маси або боїться набрати зайву вагу, має місце взаємодія харчового драйву з емоційним патерном «печаль- гнів»: людина їсть, щоб звільнитися від печалі, і при цьому картає себе за нестриманість.

К. Хорні (Хорні, 2000) вважає, що ненаситність, що виявляється в жадібності як спільній рисі характеру і виявляється в їжі, є однією 3 характерних особливостей невротичної потреби в любові, причому жадібність може виникати або посилюватися, коли зростає ворожість або тривожність. Результати дослідження R.-J. Milligan, G.Waller (Milligan, Waller, 2000) в дослідженнях за допомогою методики Спілбергера показали, що переїдання пов'язано 3 високим рівнем прихованого гніву і виконує функцію уникнення його переживання, а блювота - 3 високим рівнем стану гніву і полегшує, таким чином, цей стан.

Порівняльне дослідження рівня агресії, проведене за допомогою опитувальника Басса - Дарки у людей з надмірною і нормальною масою, дозволило встановити, що у випробовуваних з надмірною масою і ії коливаннями рівень ворожості значно вище, ніж 
у випробовуваних $з$ нормальною і стабільною масою (Ізард, 2000). Це пояснюють фрустрацією і незадоволеністю, які пов'язані з неможливістю підтримувати досягнуту після чергової дієти масу тіла. У всіх повних жінок виявилися вищими індекси агресивності і ворожості, показники вербальної, фізичної і непрямої агресії, образи і підозрілості. Згідно з цими результатами повні жінки більш схильні до вираження своїх негативних почуттів через форму і зміст словесних звернень - криками, лайкою, погрозами, а також до прояву ненапрямлених вибухів люті, що виражаються, наприклад, в шпурлянні речей, грюкання дверима при догляді, стукання по столу і т.п., тобто в непрямій агресії. У повних жінок більш виражена схильність до недовіри і обережного відношенню до людей, що виникає з переконання, що оточуючі мають намір заподіяти їм шкоду, - наслідок проекції власної ворожості на оточуючих. Виражене у повних жінок відчуття несправедливості по відношенню до них долі або інших людей часом проявляється у вигляді заздрості і ненависті до людей.

Досліджуючи вплив ідеалу жіночої краси на настрій і задоволеність тілом у жінок, L. Pinhas et al. (Pinhas, Toner, Ali et al, 2000) відзначили підвищення рівня депресії і гніву у жінок після перегляду моделей, які рекламують жіночий одяг, причому жінки, особливо не задоволені своїм тілом або мають такі психологічні особливості, пов'язані з порушенням хачової поведіки, як міжособистісну недовіру і почуття неефективності, виявилися більш схильними до впливу цих образів, ніж інші випробовувані.

Люди сприймають себе такими, що володіють небажанною ідентичністю, яку вони самі собі або інші їм приписують характеристики, що підривають їх ідеальний образ «Я». Переживання 3 приводу володіння небажанною ідентичністю викликає почуття сорому, яке обертається переживанням гніву.

В результаті дослідження образу тіла з'ясувалося, що жінки 3 надлишковою масою набагато частіше відчувають дискомфорт з приводу своєї зовнішності. Однак жінки, які повні з дитинства, на відміну від розповнівших жінок не засмучувались, порівнюючи свій актуальний зовнішній вигляд з тим, який був у них в більш ранньому віці. У жінок, повних 3 дитинства, надлишкова маса не впливає на потребу в спілкуванні.

За даними Ю.Л. Савчикової (Савчікова, 2005), результати опитувальника Міні-мульт свідчать про недостатню гнучкість, злопам'ятність повних жінок, їх схильність до формування надцінних ідей, наприклад ідеї про несхвальне ставлення до них 
оточуючих або ідеї схуднення. Дані опитування жінок, що страждають на ожиріння, в порівнянні з контрольною групою говорять про їх тенденції використовувати симптоми своїх соматичних захворювань, як засіб уникнення відповідальності, в тому числі за надмірну масу, а також про прагнення звернути на себе увагу, демонстративності, поверховості почуттів і інтересів. У жінок, розповнілих в дорослому віці, також було виявлено найвищі показники депресії і психастенії.

У всіх повних жінок часте відчуття дискомфорту з приводу свого тіла було пов'язане 3 депресією. Однак тільки у жінок, які розповніли в дорослому віці, невдоволення своїм тілом корелювало з реальним збільшенням індексу маси тіла. У цих жінок і в контрольній групі був виявлений взаємозв'язок невдоволення власним тілом з переїданням (показниками екстернальної і емоціогенної харчової поведінки), в той час як у жінок, повних з дитинства, невдоволення власним тілом було пов'язано 3 нездатністю або небажанням обмежувати себе в їжі. Показники опитувальника Мінімульт за шкалами психопатії, паранойяльності i шизоидности корелювали 3 показниками екстернальної хачової поведінки у жінок, повних 3 дитинства, i обмежувальної - у розповнілих.

\section{Висновки.}

- У 95\% випадків в основі ожиріння лежить нейрохімічний дефект церебральних систем, які регулюють харчову поведінку і гормональний статус

- Ранніми ознаками порушеної харчової поведінки $є$ зміни у психологічному статусі, які характеризуються появою несприятливих психічних реакцій: тривожності, фрустрації, ригідності, дратівливості та агресивності

- Характерологічними особливостями, взаємопов'язаними 3 порушеннями харчової поведінки у повних жінок, $є$ поєднання підвищеної чутливості 3 емоційною холодністю і відчуженістю в міжособистісних відносинах, конфліктність, агресивність, нестійкість настрою, образливість, невпевненість в собі, схильність до тривоги.

\section{Література:}

1. Бессесен Д.Г., Кушнер Р. Избыточный вес и ожирение. М.: БИНОМ, 2006.

2. Вознесенская Т. Г., Сафонова В. А., Платонова Н. М. Нарушение пищевого поведения и коморбидные синдромы при ожирении и методы их коррекции // Журн. неврол. и психиатр.-2000.- № 12.- С. 49-52. 
3. Крылов В. И. Пограничные психические заболевания с нарушениями пищевого поведения.- С.Пб.: Изд. дом «Шанс», 1995.— 112 с.

4. Креславский Е. С. Избыточная масса тела и образ физического Я // Вопр. психол.1987.—№ 2.— С. 113-117.

5. Малкина-Пых И.Г. Психосоматика. Справочник практического психолога. М.: ЭКСМО, 2005.

6. Менделевич В.Д. Клиническая и медицинская психология: учебное пособие для вузов. 5-е изд. М.: МЕДпресс-информ, 2005.

7. Пезешкиан Н. Психосоматика и позитивная психотерапия.- М.: Медицина, 1996.

8. Greeno C.G., Wing R.R. Stress-induced eating // Psychol. Bull.— 1994.— Vol. 115, № 3. - P. 444-464.

9. Kaplan H.I., Kaplan H.S. The psychosomatic concept of obesity// J. of Nerv. and Ment. Dis. - 1957.— Vol. 125.— P. 181-201.

10. Musante G. J., Costanzo P. R., Friedman K. E. The comorbidity of depression and eating dysregulation processes in a diet-seeking obese population: A matter of gender specificity // Int. J. Eat. Dis.— 1998.— Vol. 23, № 1.—P. 65-75.

11. Савчикова Ю.Л. Психологические особенности женщин с проблемой веса: дисс. канд. психол. наук. СПб., 2005.

12. Arnow B., Kenardy J., Agras W.S. The emotional eating scale: the development of a measure to assess coping with negative affect by eaters // Ibid. - 1995.— Vol. 18. - P. 7990.

13. Изард К. Э. Психология эмоций: Пер. с англ.-С.Пб.: Питер, 2000.— 264 с.

14. Хорни К. Невротическая личность нашего времени: самоанализ.- М.: Прогресс; Ювента, 2000.- 480 c.

15. Milligan R.-J., Waller G. Anger and bulimic psychopathology among nonclinical women // Int. J. Eat. Dis.—2000.— Vol. 28, № 4.- P. 446-450.

16. Carmody T. P., Brunner R. L., Jeor S. T. St. Hostility, dieting, and nutrition attitudes in overweight and weight-cycling men and women // Ibid.— 1999.— Vol. 26, № 1.— P. 37-42.

17. The effects of the ideal of female beauty on mood and body satisfaction / L. Pinhas, B.B. Toner, A. Ali et al. // Ibid.— Vol. 25, № 2.— P. 223-226.

18. Вознесенская Т. Г., Дорожевец А. Н. Роль особенностей личности в патогенезе церебрального ожирения // Сов. мед.- 1987.—№ 3.- С. 28-32. 
19. Ferguson T. J. Unwanted Identities: A Key Variable in Shame-Anger Links and Gender Differences in Shame // Sex Roles: A J. of Research. Feb, 2000.— P. 83-92.

20. The Dutch Eating Behavior Questionnaire (DEBQ) for Assessment of Restrained, Emotional, and External Eating Behavior / T. van Strien, J.E.R. Frijters, G.P.A. Bergers, P.B. Defares // Int. J. Eat. Dis.— 1986.— Vol. 5, № 2.— P. 295-315.

21. Heatherton T.F., Baumeister R.F. Binge eating as escape from self-awareness // Psychol. Bull.- 1991.— Vol. 110(1).- P. 86-108.

22. Данильченко Т.В. Особливості формування першого враження // Соціальна психологія. - 2004. - № 3(5). - с.132-144.

23. Istvan J., Zavela K., Weidner G. Body weight and psychological distress // International Journal of Obesity. 1992. Vol. 16(12). P. 999-1003.

24. Савчикова Ю.Л. Психологические особенности женщин с проблемой веса: дисс. канд. психол. наук. СПб., 2005

\section{Checklist submission}

MHGC Proceedings provides the following list in order that, authors willing to submit a paper, can check the presence of each item and submit afterwards (we also provide an example for the use of bullets and numbering in different levels):

1. Contacts information (for lead author):

\begin{tabular}{|r|l|}
\hline E-mail & Lisova.1975@gmail.com \\
\hline Postal address & Kyiv, Ukraine \\
\hline Telephone or Mobile number & \\
\hline
\end{tabular}

2. Keywords

3. The paper has been spellchecked and grammar-checked

4. References are in the correct format for this journal (APA Style)

5. Any material with copyright has been authorized by the owner 